\title{
Regional Competitiveness in Albania under the Focus of Labor Management Relations
}

\author{
Dr Elenica Pjero
}

Business Department, Economy Faculty, Vlore, Albania,

Email: elapjero@yahoo.com

Prof. Dr Albert Qarri

Rector of "Ismail Qemali" University of VIore, Albania, Email: bertiqarri@gmail.com

\section{Prof.Assoc. Dr.Alba Dumi}

Director of Graduate School, "Ismail Qemali"Vlore University, Albania, Business Department,

Doi:10.5901/ajis.2014.v3n3p501

Email:alba.besi12@gmail.com

\begin{abstract}
The paper analyzes main aspects of public administration reform in Albania during the last decade, focusing especially on last three years. At the beginning, the role of Public Administration Department has been highlighted and discussed. Later, the author identifies three important ingredients of reforming efforts: functional and structural reform, extension of scope of legislation related to civil service and wage system reform. The latest has been discussed in details for different public sectors like education, health service etc. The contribution of Training Institute of Public Administration to reform process has been also briefly identified. Albania is open to foreign investment and increasing FDI is a top priority for the Albanian government. Albania has put in place a liberal foreign investment regime, including a 10 percent flat corporate and income tax and has taken measures to improve the business climate by streamlining business procedures through e-government reforms. These improvements along with NATO membership and progress toward EU integration have contributed to the increase in investor interest during the last couple of years. Promising sectors for foreign investors and include: energy (including alternative energies), mining, transportation, telecommunications, and tourism. The country's geographic position places it at the crossroads of Western and Eastern Europe. A stable U.S. ally, Albania is a member of NATO, the WTO and is in the process of applying for candidate status in the European Union.
\end{abstract}

Keywords: Administration reform, EU integration, Candidate status, Tax reform, Strategic objectives

\section{Introduction}

We want to start this paper research with a famous English economist, Artur Pigou definition:

"It is planned that divergences between private and social net product of the kinds we have so far been considering cannot, like divergences due to tenancy laws, be mitigated by a modification of the contractual relation between any two contracting parties, because the divergence arises out of a service or disservice to persons other than the contracting parties. It is, however, possible for the State, if it so chooses, to remove the divergence in any field by "extraordinary encouragements" or "extraordinary restraints" upon investments in that field. The most obvious forms which these encouragements and restraints may assume are, of course, those of bounties and taxes (Pigou A)

FDI during the first nine months of 2009 is estimated to have reached 580 million euro despite optimistic GOA projections for 2009 fueled mainly by strong investor interest witnessed during 2007-2008. A large part of FDI is due to privatizations. The Albanian government collected 103 million Euro from the privatization of 76 percent of the shares of the distribution arm of Albanian Power Corporation; 48 million Euro from the privatization of 12.6 percent of AMC state controlled shares; 5 million euro from the privatization of $40 \%$ of GOA controlled shares of the United Bank of Albania. INSIG (insurance company) privatization failed during the negotiation process with the winter and it might take place during 2010. Leading investor nations in Albania include: Italy, Greece, Turkey, Austria, Germany, Canada, Spain and the U.S. Foreign investment focuses on financial sector, oil and gas production, telecommunications, mining, metallurgy, 
energy, manufacturing and cement production.

\subsection{Albania and its relations with internal and external markets}

The development of the EU and the completion of the internal market have increased the imperative that member countries develop certain administrative capacities to deal with both the transposition and the effective implementation of the growing body of the acquis communautaire. In addition, the EU enlargement experience in the East and the challenging scope of reforming post-communist administrations have seemingly pushed the Union towards developing and refining a criterion of administrative capacity. (Belishova 2013).

The EU, thus, intended to avoid the possibilities that this group of states disrupted the functioning of the Union once they became part of it. The process of downsizing the government started at the end of 2005 and has been implemented through the first quarter of 2006. There are actually 14 ministries, compared to previous 17 . This reduction has been associated with decrease of political positions in ministries by $21 \%$, which in turn resulted in considerable decrease of supporting staff. ( Alderman, H., (2002)

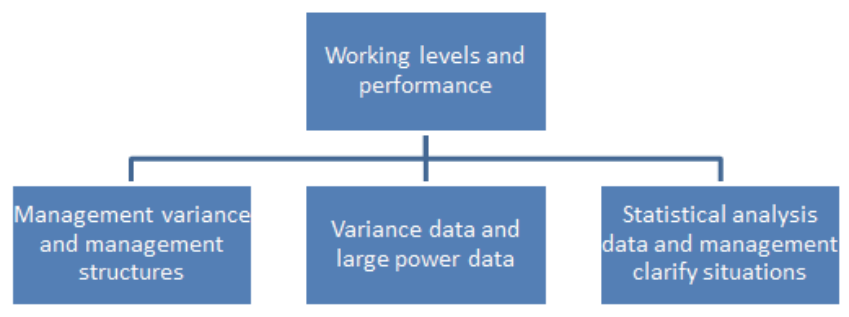

Tab 1: Four dimensions of PD management levels, Source: Kantter K 1989

\subsubsection{Albania's tax system and foreign and domestic investors support.}

Albania's tax system does not discriminate against foreign investors and no distinction is made between foreign and domestic investors. The e-taxes reform is progressing and as of January 2008 , corporate income tax was reduced from $20 \%$ to $10 \%$, one of the lowest in the region. In addition, as of May 2009-2010, the social insurance contribution payable by employers will be reduced again from $20 \%$ to $15 \%$, down from $29 \%$ in 2006 . Businesses can file their tax returns and social insurance declarations electronically in 12 cities including Tirana and electronic payment of taxes is also possible through certain banks.(Callon A, 2006)(Mazreku V 2010) At the same time, a structural reform occurred, which consisted in redefinition of core governing functions, through reformulating of missions, strategic objectives, organizational structures, functions and job descriptions. Within the frame of this reform, a new structure has been implemented in all ministries. Its basic assumption requires that in every ministry core functions should be grouped in four main pillars: policy-making • regulation • services delivery • supporting services (Selenica B, 2001)

Supported by donor assistance and international and local NGO's the city initiated a community-based development strategy in the in-formal. The program brought together local government teams, NGO's and residents to formulate a development plan for the neighborhood define priorities for improvements and determine equitable costsharing formulas to finance infrastructure. This partnership led to the upgrading of roads and electrical networks, the construction of community buildings and schools, improved public spaces and programs for youth housing. The newly adopted strategies in the central public administration integrate the following concepts: transparency, predictability, accountability, adaptability, and effectiveness.

\section{Literature Review and Hypotheses}

In the case of multifunctional structures, the priorities of functions decide and a general director leads the pillar, having so reduced the number of persons reporting to the general secretary of the ministry and grouping the functions under "a single roof". As a result the conflict between roles is avoided and a considerable amount of resources will be directed to policy-making strategy formulating processes. Focusing in a single process could also increase the capacity and specialization level of civil servants in a short-time period. 
The law "On Concessions," No. 9663, dated December 18, 2006, established the necessary framework for promoting and facilitating the implementation of privately financed concessionary projects enhancing transparency, fairness, efficiency and long-term sustainability in the development of infrastructure and public service projects. First, the application of EU conditionality in this area seems to suggest that a state can hardly be refused entry into the EU on the basis of the administrative capacity alone. Even when all the aforementioned elements of the administration are absent, the country could still be judged to meet the general political criteria of accession.

Increasingly, in recent years, employers have succumbed to an urge to use "labor relations consultants" who are usually either lawyers or psychologists, to prevent a union from gaining bargaining rights or to get rid of an established union through a decertification election. Informed estimates place the number of such consulting firms at an absolute minimum of 1,000 , with at least five times that number of individuals directly involved in what unions bitterly call "union busting" and many employers contend is merely the providing of assistance to employees who genuinely want a nonunion environment. ( Bradler\& Sediss 1989)

$\mathrm{Ty}+\mathrm{Tx}=\frac{\hat{\hat{\beta}}}{\operatorname{sE\beta }}$

\begin{tabular}{|c|c|c|}
\hline Number of employers & consulting firms & Environment indicators \\
\hline $\mathrm{X}_{1}$ & 20 & $\mathrm{ut}$ \\
\hline $\mathrm{Y}$ & 4.26 & $\mathrm{~A} 0+\mathrm{ai}$ \\
\hline
\end{tabular}

$Y=a_{0}+$

$a_{1} X_{1}+u_{t} Y=P B B X_{1}=B B, a_{0}, a_{1}=$ Regressions Indicator

$Y=-39.6+2.8 X_{1}(45.5)(0.12)$

$a_{0}=-39.6 a_{1}=2.8 R^{2}=0.96$ F-Test $=413$

A more formal, institutional driven approach to the reform process was also implemented. Specialized governmental structures such as the Central Unit for the Reform of Public Administration (Ministry of Administration and Interior), the Superior Council for the Reform of Public Administration, Coordination of Public Policies, and Structural Adjustment (under the direct supervision of the prime minister), and Unit for Public Policy were created. The aim was to identify the strategic actors involved in the process of administrative reform and to create national networks for the promotion of the reform. (Hintea, 2006:13)

\subsection{Labor relations consultants}

Some members of this new growth industry at times advise their employer-clients to engage in activities that are quite illegal under national labor policy, such as placing agents in the workplace to spy on employees; harassing and discharging union members; avoiding the hiring of blacks (who are -in the opinion of at least one practitioner in this line of work-"more prone to unionization than whites "); and initiating decertification elections. Others guide managements in engaging in bad-faith, uncompromising bargaining so as to provoke a strike in which the employer can replace unionized employees with a nonunion work force. (Alderman H., (2002)

Expertise is also provided to employers who wish to legally move their unionized work to their nonunion facilities (some of which have been newly created just for this purpose). Given the current state of labor relations law, will explain in much more detail in this paper research, consultants have a wide area of lawful tactics and strategies to place at their clients' disposal and by no means need move beyond what public policy allows in order to be effective. In addition to providing such personalized services, some consultants hold seminars open to all comers for a fee.(Bankedel S, Seggel S 2013)

\subsection{The analysis of the EU impact over public administrations structure}

The engagement of senior government officials in the dissemination of project information secured commitment among communities and farmers. Albania has improved public procurement by approving a new law and introducing eprocurement. The new law takes into account the principles of non-discrimination and equal treatment, transparency, and legal protection of interests of bidders on public contracts.

Direct tendering has been abolished and criteria to identify abnormally low bids have been introduced. The Public Procurement Advocate was established as an independent institution reporting to parliament. However, it has no particular executive powers and its functions duplicate the monitoring tasks of the PPA. 
Decisions on appeals are taken by the same unit of the PPA that is responsible for interpreting the law and giving advice to contracting authorities. Current procedures for handling complaints still do not meet recognized international standards. Despite progress, its application is hampered by technical problems, the insufficient IT capacity of many contracting authorities and corruption in drafting tender documents. Companies continue to experience issues with transparency in specifications and communication in competing for public tenders.

\subsection{The improvements in the public procurement legislation and the impact of $E U$}

Overall, the improvements in the public procurement legislation are advancing while the proper-enforcement of the law is still a work in progress. The 'bureaucratic' criterion was, thus, formally outlined as part of enlargement conditionality. It was also by and large detailed down, especially in the EU documents monitoring accession stages. Yet, most analysis of the EU impact over post-communist administrations finds that the criterion was hardly used to speed up or slow down each country's path to membership according to the respective progress of reforms. (Abbas, S \& Christensen, $E$ (2007)

Even though generally the employees of the Public Administration were evaluated very good and good, still there is work that needs to be done regarding the personal qualification. The personal qualification often is referred to the trainings that the employees of the public administration, which is very important. Until nowadays only a small part of the employees are involved in doctorate studies. The employees are still far from career commitments, and this is why only a few of them represent scientific publications for their sector. The 1997 commission's opinions on candidate countries readiness to accede to the EU were quite telling in this regard. The majority of the candidate countries did not encounter any problems to meet the public administration criteria, although only few had passed a civil service law, a strategy of implementation and even less so specific civil service management institutions back then. One of its major amendments includes a better regulation for unsolicited proposals and of public-private partnerships in general. (Albanian Progress report 2013)

The law applies to a wide range of sectors, including:

- $\quad$ transport (railway system, rail transport, ports, airports, roads, tunnels, bridges, parking facilities,

a) public transport);

b) generation and distribution of electricity and heating;

c) production and distribution of water, treatment, collection distribution and administration of waste water, irrigation, drainage, cleaning of canals, dams;

d) collection, transfer, processing and administration of solid waste;

e) telecommunication;

f) education and sport;

g) health;

h) tourism and culture;

i) prison infrastructure;

j) recycling projects, rehabilitation of land and forests, in industrial parks, housing, governmental buildings, service of maintenance of IT and data base infrastructure;

k) natural gas distribution;

l) management contracts or provision of public services including those related to sectors specified above.

In order to promote investments in priority sectors the GOA may offer concessions to local or international investors for the symbolic price of one euro. The GOA, with the approval of the Minister of Economy, authorizes concessions in other sectors besides the ones listed above. The law does not apply to concessions that require a separate operating license unless that is included in the framework of the concession agreement.

\section{Methodology and Research Goal}

At the same time, a structural reform occurred, which consisted in redefinition of core governing functions, through reformulating of missions, strategic objectives, organizational structures, functions and job descriptions. Within the frame of this reform, a new structure has been implemented in all ministries. Its basic assumption requires that in every ministry core functions should be grouped in four main pillars: $\bullet$ policy-making $\bullet$ regulation $\bullet$ services delivery $\bullet$ supporting services

\subsection{Analyzing data}

The performance evaluation is mainly characterized by qualitative indicators and there are only a few quantitative 
indicators. According to the data collected from the questionnaires the employees asses the importance of the performance evaluation in $100 \%$, they concretize it with the objectivity in the evaluation. To the question "Is the performance evaluation objective in your institution?"- $20 \%$ answered positively, $54 \%$ avoided the answer and $26 \%$ of them think that it is dictated from the subjectivity of the leaders. According to the questionnaire the major part of the questioned employees think that the performance evaluation takes to conflicts between the subordinate and the superiors.

And this is why we pretend that the performance evaluation does not justify its objectives because it is based only in the commitment related to the job. To create the conviction for this problem a hypotheses came out:

$\mathrm{H} 1$ : The performance evaluation in the public administration is objective.

The question "Is the performance evaluation objective?" was analyzed in details and the answers were evaluated from 1-10 points each, nine of the questioned persons were leaders and employees.

The respective evaluations are presented below:

\begin{tabular}{|l|c|c|c|c|c|}
\hline $\begin{array}{c}\text { Environment } \\
\text { indicators }\end{array}$ & $\begin{array}{c}\text { Number of } \\
\text { employers }\end{array}$ & $\begin{array}{c}\text { consulting firms and } \\
\text { ADP changes }\end{array}$ & $\begin{array}{c}\text { strategic } \\
\text { objectives }\end{array}$ & $\begin{array}{c}\text { strategic decision } \\
\text { making }\end{array}$ & $\begin{array}{c}\text { organizational } \\
\text { structures }\end{array}$ \\
\hline First choice & 1 & 8 & 3 & 9 & 3 \\
\hline Second choice & 4 & 7 & 5 & 6 & 4 \\
\hline
\end{tabular}

We join both choices in one and keep the identity by underlining (for ex. the second choice)

\begin{tabular}{|c|c|c|c|c|c|c|c|c|c|}
\hline values & 4,4 & $\underline{4,3}$ & $\underline{5,5}$ & $\underline{6,1}$ & $\underline{7,3}$ & 7,2 & 7,4 & 8,2 & 9,1 \\
\hline Ranks & 1 & 2 & 3 & 4 & 5 & 6 & 7 & 8 & 9 \\
\hline
\end{tabular}

We calculate the sum of the first choice and the average

$$
\begin{aligned}
& \mathrm{R}_{\mathrm{10}}=6+7+8+9 \\
& \mathrm{M}_{\mathrm{R}=}=\frac{n 1(n 1+n 2+1)}{2}=\frac{4(4+5+1)}{2}=20
\end{aligned}
$$

We calculate the quadratic average derivation of the Man Whitney criteria

$$
\mathrm{S}_{\mathrm{R} 1}=\sqrt{\frac{n 1 n 2(n 1+n 2+1)}{12}}=\sqrt{\frac{4.5(4+5+1)}{12}}=4.8
$$

We calculate the factual value $\mathrm{Zf}$ and are compared with $\mathrm{Zk}$ that is the statistic value at a critic level.

$\mathrm{Zf}=\left(\mathrm{R}_{1 \mathrm{~m}}-\mathrm{MR}_{\mathrm{R}}\right) / \mathrm{SR}_{1}=(30-20) / 4.8=2$

Zf $>$ Zk ; $2>1.76$

This calculation shows that the hypothesis is not valid.

In the performance evaluation the subjectivism has high levels. It is important to find other parameters for the evaluation, and this is a commitment of this article in the future.

On other cases we are studying rank of $P A D$ indicators like this: $Y 0>Y 1, Y 4>Y 2$, so $Y N-1<Y N$

The results from this article show that the performance evaluation is a very important element in the Public Administration, and it effects the improvement of the work in the state and central bodies.

- The performance evaluation conditions the emplacement and the implementation of the standards as referential points. Emplacing standards would increase the responsibility for each post in the Public Administration and will help in monitoring the performance of the institution.

- Despite the continuous improvements after 1990- 2013, there are still lacks and gaps in the performance evaluation and this harms the public opinion for the Public Administration.

- One of the lacks is the considerable subjectivism during the performance evaluation, which was proved by the contemporary methods, with the Man Whitney method for the minor choices where $\mathrm{Zf}$ is larger than Zk, and this showed that the hypothesis about the objectivity of the performance evaluation is not available.

\subsection{Economic policy essentials}

- The main political parties agree on the key essentials of a market economy, despite a tense political environment. Macroeconomic stability was broadly preserved, but vulnerabilities remain. The budget deficit exceeded the target in 2012. This led to the statutory debt ceiling of 60\% of GDP enshrined in the budget law being breached and abolished. The privatization process suffered certain setbacks. Albania submitted its seventh Economic and Fiscal Programmers, for 2013-15, in January. The programmer's medium-term 
macroeconomic scenario is optimistic. Its coverage of risks to the macroeconomic and budgetary outlook is insufficient, and the approach to addressing structural obstacles to growth lacks a clear strategy and targeted policy measures. Overall, the consensus on the main fundamentals of a market-oriented economy has been maintained.

Source: Open Systems for Social Transformation, Toriccelli A 2014,Milano Italy

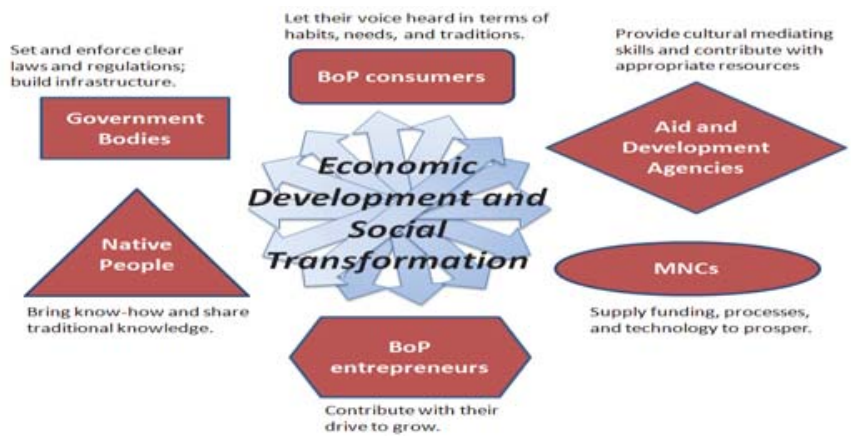

\subsubsection{Macroeconomic stability}

According to preliminary data, economic growth slowed to $1.6 \%$ in 2012 from 3.1\% a year earlier. Financial constraints, low confidence among consumers and investors and the presence of spare production capacity held back private consumption and investment spending. Total gross fixed capital formation decreased by around 5\% in 2012 compared with the previous year. Migrant workers' remittances increased slightly, by some $1.6 \%$ in 2012, but dropped by $33 \%$ on an annual basis in the first six months of 2013. Private consumption remained at low levels. Net exports were the main contributor to economic growth, with foreign sales holding up while imports declined.

\subsubsection{Policy-making strategy and the job descriptions}

After falling in four consecutive quarters, economic sentiment indicators started to climb in late 2012 and early 2013, but real GDP only grew by $1.7 \%$ in the first quarter of 2013 in annual terms, reflecting still sluggish domestic spending. Foreign demand continued to contribute positively to growth. Per capita GDP in purchasing power standards was estimated at $30 \%$ of the EU-27 average in 2012, unchanged from 2011. Alfredo Schclarek (2004)

\section{Limited Liability Company}

This is the most common legal form of conducting business in Albania. Its members enjoy limited liability and, unless the articles of the bylaws provide otherwise, members have the right to transfer their shares to other persons, upon decision of three fourths of the shareholders. It can be established by one or more partners, legal or natural persons, who are responsible for losses only to the extent of their contribution to the capital of the company. The minimum required capital for this form of company is approximately $\$ 1$ USD. The capital is divided into shares and there are no mandatory requirements for their nominal value. The contributions to capital can be in cash or in any asset, tangible or intangible.

The law does not permit contributions in services. Administrators nominated through the General Assembly of the shareholders manage the limited liability company. Extraordinary decisions, increases or decreases in the share capital, mergers and acquisitions are to be approved by at least three quarters of the capital shareholders. The law requires annual financial statements to be prepared by the company. The transformation of this form of business into unlimited and limited partnership is subject to decision of general assembly of the shareholders that takes valid decisions upon majority vote of $3 / 4$ of shareholders and after approval of financial statements for the last two years.

\subsection{Foreign Direct Investment Statistics}

The FDI has increased although it still remains among the lowest in the region. The cumulative FDI is also the lowest in 
the region. Market entry and exit Business registration and licensing continued to perform well through the established network of one-stop shops. Some improvement was made to the business registration system by making the notarization of incorporation documents optional. In 2012 the number of new businesses registered grew by 8\% year-on-year; they make up $12 \%$ of all active enterprises. A registry of certified bankruptcy administrators was set up and 23 bankruptcy administrators were licensed until April. However, the time taken and procedures for market exit remain slow. In 2012 the number of requests for voluntary business closures went up by $14 \%$ from a year earlier. Overall, Albania has made incremental improvements to its well-functioning procedures for starting a business. Market exit procedures remain slow. (Albanian progress report 2010)

\section{Recommendation}

Albania, one of the smallest and poorest countries in Eastern Europe, has experienced a transition marked by sharp economic swings and periods of civil strife. The early phases of decentralization witnessed the transfer of political autonomy and limited administrative and fiscal authority, to local governments, inadequate legislation outlining central/local responsibilities, scarce financial resources and deficient infrastructure strained the capacity of local governments to mange urban services. In January 2000, the government promulgated a national Strategy for Decentralization and Local Autonomy which includes lows to strengthen the autonomy of local governments and increase their capacity to manage local infrastructure and services. To work closely with Community- Based organizations so as to enhance their capacity to participate in development programs and strengthen the City Council's capacity to respond to requests from communities(Alfredo Schclarek (2004)

- To adopt a new approach to Environmental Planning and Management based on capacity building.

Supported by donor assistance and international and local NGO's the city initiated a community-based development strategy in the informal. The program brought together local government teams, NGO's and residents to formulate a development plan for the neighborhood define priorities for improvements and determine equitable costsharing formulas to finance infrastructure.

This partnership led to the upgrading of roads and electrical networks, the construction of community buildings and schools, improved public spaces and programs for youth. Clarifying the legal status of residential land and formalizing an urban plan resulted in the sufficient leveraging of community and house4hold resources to provide infrastructure and build new housing. Finally, the engagement of senior government officials in the dissemination of project information secured commitment among communities and farmers.

- To work closely with Community- Based organizations so as to enhance their capacity to participate in development programs and strengthen the City Council's capacity to respond to requests from communities. To adopt a new approach to Environmental Planning and Management based on capacity building.

The CIP upgraded infrastructure, enhanced participation and built the capacity of CBOs and stakeholders. CIP strengthened institutional capacity by establishing program offices in each community, forming steering committees made up of representatives from all stakeholder groups and formalizing institutional links between the relevant partners and information for decision-making and monitoring of performance among the stakeholders altered attitudes and understanding of roles and responsibilities. Communities have agreed to earmark part of stakeholders as a partner in urban development ensures the sustainability of these assets.

\section{Conclusions}

Sustained political pressure and the demonstrated capacity of municipalities to manage their responsibilities were the driving forces for local administrative and fiscal autonomy. Initial assessments suggested that decentralization did improve the quality of service delivery and foster a new, user oriented attitude, facilitating the transition from a centrally planned to a market economy.

The act for support of local investment committed the municipality to cover 50 percent of the cost of water, sewerage and power lines, 70 percent of the cost of roadbeds and sidewalks and 100 percent of the cost of drainage and street paving. The cost sharing formula can be modulated to take into consideration issues of equity and cost burden. As an incentive to private rehabilitations of buildings, investors are granted a three year exemption from property taxes. This is a highly significant feature of infrastructure programs and carries important implications for local development. The conclusions of this paper research are following:

1. Introducing participatory planning and community-based development processes through neighborhood development committees and street representatives working in partnership with the city 
2. Creating an enabling environment for private investment

3. Empowering citizens to pursue their own self improvement

4. promoting privatization of the housing a stock and fostering the development of micro- enterprises

5. Ensuring the sustainability of activities initiated

6. Promoting the reliability of successful initiatives.

Albanian government will work on these points:

- A dynamic local government leadership

- A coherent strategy acted upon with determination

- A healthy climate of cooperation with business

- Local government's investment initiatives to jumpstart the stagnant economy

- Creative use EU funds to implement local policy

- Efficient municipal administration

- Coherent links among urban planning, infrastructure and economic developmement.

\section{References}

Alfredo Schclarek (2004): "Debt and Economic Growth in Developing and Industrial Countries", f 15 URL:http://ief.eco.unc.edu.ar/files /workshops/2006/7marzo06_DebtGrowth.p df

Abbas, S and Christensen, E (2007): The Role of Domestic Debt Markets in Economic Growth: An Empirical Investigation for Loëincome Countries and Emerging Markets, IMF Working Paper, ff 20-23 URL:http://www.imf.org/external/ pubs/tt/wp/2007/wp 07127.pdf

Banka Botërore, (2006): "Shqipëria Ristrukturimi i Shpenzimeve Publike për të Mbështetur Rritjen", Një Rishikim i Shpenzimeve Publike dhe i Kuadrit Institucional, f 14 URL:http://siteresources.Worldbank.org/INTALBANIA/Resources/PEIRPPT_Overall_PEIR_al.pdf

Banka Botërore (2010): "Shqipëria: Axhenda e Re e Rritjes Ekonomike Memorandum Ekonomik i Vendit", Raport nga BB, Nr. 53599-AL, ff 2-3

Commission of the European Communities, "Council directive of 27 June 1985 on the assessment of the affects of certain public and private projects on the environment", pg 123-129

Official Journal of the European Communities, L175, pages 40-48.

" Towards sustainability-a European Community programme of policy and actions in relation to the environment and sustainable development" COM(92) 23 final- vol 11 ( Commission of the European Communities), 1992.

Kettl, D.F.(2006) Modernizing Government: The Way Forward-A Comment. International Review of Administrative Sciences, 72(3), pp.313-7.

Lapsley, I (2009), New Public Management: the cruelest invention of the human spirit?, Abacus: Accounting, finance and business studies, vol.45, N. 1, pp. 1-21.

Mihai, A. (2005), Romanian Central Public Administration and the challenges of Europeanization, in Working Paper FG2, 2005/03, October, SWP Berlin.

Mintzberg, H., (1996), 'Managing government, governing management'. Harvard Business Review, 74: 3, pp75-83.

Mussari, R., Cepiku, D., (2007) Public administration reform in transition, Public Management Review, 9:3,353-375.

Nikolov M. (2006), The future of local government finance. Case studies from Romania, Bulgaria and Macedonia, Skopje 